\title{
STRONG HIGH PRESSURE SYSTEMS INFLUENCING THE WEATHER IN POLAND DURING THE PERIOD 1971-2000
}

\author{
ZUZANNA BIELEC-BĄKOWSKA
}

Department of Climatology, Faculty of Earth Sciences, University of Silesia

\begin{abstract}
This paper shows preliminary results of research into the occurrence of strong anticyclonic systems that influenced the weather in Poland during the period 1971-2000. The study was based on NCEP/NCAR reanalysis data, including daily values of the 1000 and $500 \mathrm{hPa}$ geopotential heights, maps of mentioned geopotential heights and maps of sea-level field pressure. With the use of these data a number of exceptionally strong high-pressure systems were identified, together with their areas of origin and subsequent development patterns. They were then broken down into five groups with similar dynamics. The numbers of systems in each group were not found to follow any significant change trends in the long term. The greatest differences between groups were identified in terms of their annual occurrence rates and centre pressure values.
\end{abstract}

Keywords: strong high pressure systems, atmospheric circulation, long-term variability, reanalyses

\section{INTRODUCTION}

Atmospheric circulation is numbered alongside solar radiation among the most important factors influencing the weather and climate. At moderate latitudes atmospheric circulation plays the strongest role during the cold half of the year, when it provides a mechanism of channelling energy from warmer zones to areas with a negative balance of radiation. From this perspective the crucial element of the European atmospheric circulation is the occurrence of situations favouring zonal flow or blocking pattern occurrence. This has been the topic of much research on atmosphere dynamics. The most important of these studies investigated the variability of air pressure distribution (Barnett 1988; Luterbacher et al. 2002; Trenberth, Paolino 1980, 1981), variability of the occurrence of circulation types or atmospheric circulation indices (Hurrel, van Loon 1997; Kożuchowski 1993; Niedźwiedź 1996; Ustrnul 1997; Wibig 1999a, 1999b). Additionally, changes of the atmospheric circulation are invoked by most of the published research into spatial and temporal changes of particular meteorological elements (Brunetti et al. 2002; Degirmendžić et al. 2004; Marsz, Żmudzka 1999; Wibig 1999c). A very important topic in research into atmospheric circulation is the investigation of the occurrence and travel paths of strong air pressure systems. Over short periods of time they exert a very strong influence on local weather (Bengtsson, Hodges 2006; Hoskins 2002; Kożuchowski 1995; 
Kłysik 1995; Romem et al. 2007; Sinclair 1997). Particular attention is given to the impact on low-pressure systems that often cause sudden changes in the value of meteorological elements and consequently substantial economic and social damage, as well as altering the mental and physical state of people. In this respect the greatest role is attributed to the frequency of occurrence, travel paths and change in pressure of strong depressions (Cornford 2002; Knippertz et al. 2000; Leckebusch, Ulbrich 2004; Ulbricht et al. 2001; Trepińska et al. 2006). Recently, the focus has slowly shifted to also include studies into the dynamics of high pressure systems. They are investigated for their impact on climate warming during the last century and a causal relationship with the occurrence of extreme climatic events, such as hot and cold waves and wet and dry spells (Baldi et al. 2006; Brunetti et al. 2001; Degirmendžić 1998; Hafez 2007; Michaels et al. 2000).

\section{Objective}

This study looks at the characteristics of strong high-pressure systems that shaped Polish weather in the period 1971-2000. It utilises earlier research that identified such systems, including their sea-level pressure, centre pressure and vertical extent. In the study an attempt to identify of the source areas and analysis of the subsequent development of these systems was made. The systems were then grouped according to their dynamics and compared for similarities in terms of frequency of occurrence and long-term variability.

\section{MATERIALS AND METHOD}

The research was based on free atmosphere data for selected grid points representing various Polish regions and spanned the study period of 1971-2000. The data comes from NCEP/NCAR reanalyses made available by the US National Centre for Atmospheric Research (http://www.cdc.noaa.gov) (Kalnay et al. 1996). It included:

- values of geopotential height $1000 \mathrm{hPa}$ at $12 \mathrm{UTC}$ for 15 selected grid points $\left(2.5^{\circ} \times 2.5^{\circ}\right)$; and

- maps of geopotential height: $1000 \mathrm{hPa}$ and $500 \mathrm{hPa}$ and the sea-level pressure field at 12 UTC.

Earlier research identified anticyclonic systems with a very strong influence on the weather in Poland during the study period (Bielec-Bąkowska 2007). To do that five from 15 grid points were selected: $\mathrm{PL}_{\mathrm{NW}}\left(55^{\circ} 00^{\prime} \mathrm{N}, 15^{\circ} 00^{\prime} \mathrm{E}\right)$, $\mathrm{PL}_{\mathrm{NE}}\left(55^{\circ} 00^{\prime} \mathrm{N}, 25^{\circ} 00^{\prime} \mathrm{E}\right), \mathrm{PL}_{\mathrm{C}}\left(52^{\circ} 30^{\prime} \mathrm{N}, 20^{\circ} 00^{\prime} \mathrm{E}\right), \mathrm{PL}_{\mathrm{SW}}\left(50^{\circ} 00^{\prime} \mathrm{N}, 15^{\circ} 00^{\prime} \mathrm{E}\right)$, 
$\mathrm{PL}_{\mathrm{SE}}\left(50^{\circ} 00^{\prime} \mathrm{N} 25^{\circ} 00^{\prime} \mathrm{E}\right)$, located within or very close to the territory of Poland (Fig. 1). The grid points were selected to represent the country's regions characterised by the greatest difference in the occurrence of air pressure systems and the centre of the study area. At each of these points, days were identified when the geopotential height of the $1000 \mathrm{hPa}$ was particularly high, meaning that the ground level pressure was exceptionally high. The criterion was the $1000 \mathrm{hPa}$ geopotential height at more than 99 percentile. Next, maps of the geopotential height of each air-pressure levels and maps of the sea-level pressure were used to determine the vertical extent of the system, the location of its centre at the sea level in relation to the territory of Poland and the value of sea-level pressure at the system centre, defined as the value of the last closed isobar. The latter definition means that the actual pressure value at the centre was slightly higher than the one determined for the purpose of the study. Only systems that caused high air pressure values over Poland were included in the research, which left out of its scope a number of very strong and large pressure systems that may have influenced the weather of the analysed area, but the actual pressure values at the selected points failed to clear the adopted criterion (Bielec-Bąkowska 2007).

Using the results described above an attempt was made to identify the source areas and subsequent steps in the development of the strong air pressure systems

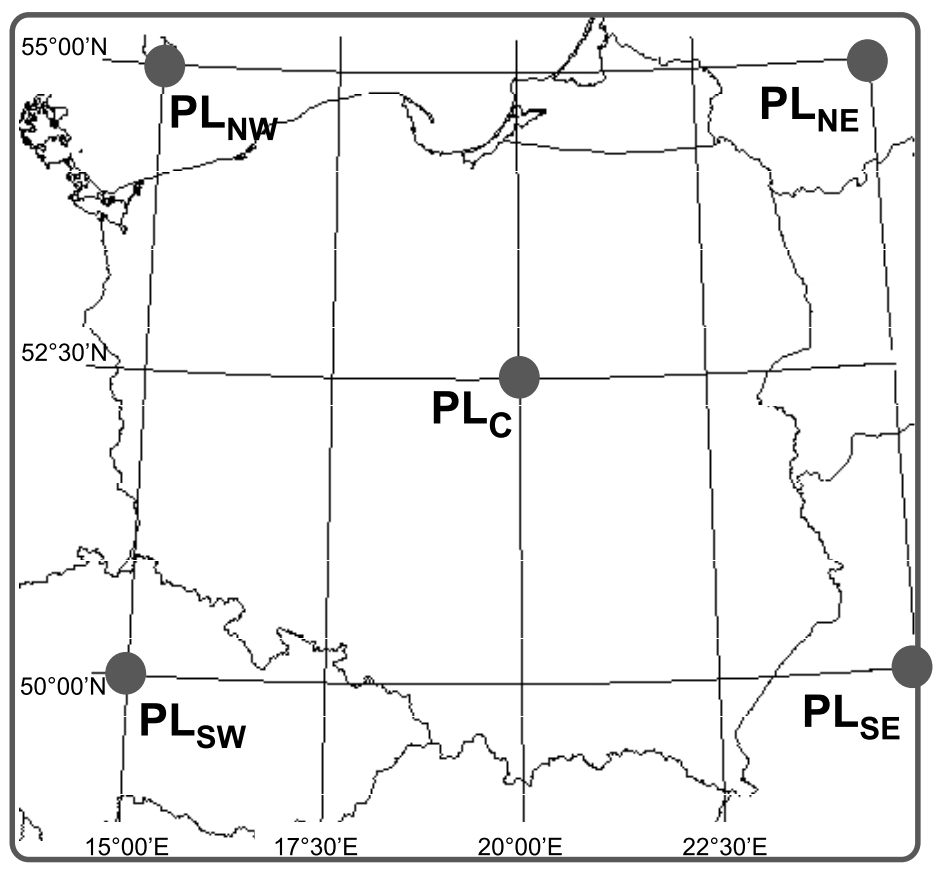

Fig. 1. Grid points used in the study

Ryc. 1. Punkty gridowe uwzględnione w opracowaniu 
driving the weather in Poland. To do that a number of characteristic groups of strong high-pressure systems were identified using sea-level field pressure maps and geopotential height maps at the pressure levels listed above. The resulting classification is of a subjective nature and carries an error margin stemming from the author's subjective assessment of each case. The high pressure systems were analysed for their annual and long-term variabilities, while each group of systems was characterised in terms of the elevation and the central value.

\section{STRONG HIGHS OVER POLAND}

The earlier research showed that between 1971 and 2000 either individual regions of Poland or its entire territory were influenced by strong high-pressure systems on 265 days, and the centre pressure values of those systems ranged from 1035 to $1060 \mathrm{hPa}$. More than $85 \%$ of those cases involved systems ranging from 1040 to $1045 \mathrm{hPa}$. The method adopted produced results similar to those obtained with generally accepted climatological rules whereby, for an anticyclonic system to qualify as exceptionally strong, it must have pressure equal or greater to the air pressure of $1035 \mathrm{hPa}$ (Kożuchowski 1995).

Most of the systems studied (more than $70 \%$ of cases) are high baric systems, or those above which there are closed isohypses on the map of the $500 \mathrm{hPa}$ isobaric level. Medium-elevated systems (where the isohypses form an anticyclonic wedge) account for approximately $15-20 \%$ of cases. Strong high-pressure systems occur mainly during the cold season and especially between December and February. It has also been noted that in wintertime they affect the southern and central regions of Poland more often (74-78\% of cases) than the northern regions (66-68\%). From May to September, exceptionally high pressure values are recorded sporadically, and only two such days were found in the study period with the pressures slightly above 1035 and $1040 \mathrm{hPa}$ (Bielec-Bąkowska 2007).

In terms of the location of the pressure centres' the western and central regions were most frequently under the influence of systems with the highest values in the centre covering much of the country's territory (more than $40 \%$ ). In the northeast and southeast the weather was influenced mostly by systems centred to the northeast (40.5\%) and east (33.0\%) of Poland. Anticyclonic systems with their centres to the southeast, south and southwest of Poland were rare, and mostly influenced southern and central regions of the country (Bielec-Bąkowska 2007).

These results inspired the author to seek answers to a number of questions: What was the duration of a single strong anticyclonic system influencing Poland? Did the identified systems emerge in the same regions and follow similar development patterns? How many of them crossed Poland and how many only reached over its territory? Do the identified systems follow any long-term trends of change, and how does their annual occurrence vary? 
To answer the first of these questions the author determined a number of sequences of days during which a single high-pressure system shaped the weather in Poland. During the study period, 112 such sequences of days were identified, and in most cases each of them corresponded to a single system. There were only three events when two different high-pressure systems accounted for the same sequences of days when a strong system disintegrated and was replaced by another strong system.

\section{STRONG HIGH CLASSIFICATION}

In the next step the research identified the source area and subsequent development of each anticyclonic system. This was not an easy task, as high pressure systems are notorious for the difficulty in pinpointing the moment when the centre of a future vast system spanning large parts of Europe emerges. Often, equally as difficult is the determination of their moving course, as they typically persist over a certain area and only slightly move their location by expanding and contracting. Anticyclonic systems can also 'go back' to an area they have left. Additionally, they sometimes develop a secondary centre, which can become the dominant centre at some stage. In spite of these reservations five groups of strong high pressure systems were identified according to their origin and subsequent development patterns:

1) Group I (GI). An area of low pressure covered northern Europe and the northern Atlantic featuring several well developed low-pressure systems, including deep systems. The rest of Europe and northern Africa were under the influence of a vague high-pressure zone, sometimes linked with the wedge of the Azores High. In this zone a single high-pressure system would emerge, typically over western and southern Europe, and normally move northwards and/or eastwards where it would slowly disintegrate (Fig. 2).

2) Group II (GII). Southern Europe and the Atlantic Ocean between $30^{\circ}$ and $50^{\circ} \mathrm{N}$ were under the influence of high-pressure zone. An anticyclonic wedge would develop over the ocean or, sometimes, over western Europe, from which a high-pressure area would develop west of the British Isles. Its centre would then move eastwards, often encompassing Scandinavia, and would next turn towards the southeast into eastern Europe and would decay over Russia or the Black Sea (Fig. 2).

3) Group III (GIII). An Arctic Sea anticyclonic wedge would expand towards the Barents Sea and Scandinavia. After two to three days over these areas a high pressure system would develop and move at a relatively fast pace southwards. Sometimes, it would stay a little longer over central or eastern Europe and then decay in the south of the continent (Fig. 2).

4) Group IV (GIV). The source area is located in eastern Russia or Scandinavia. 

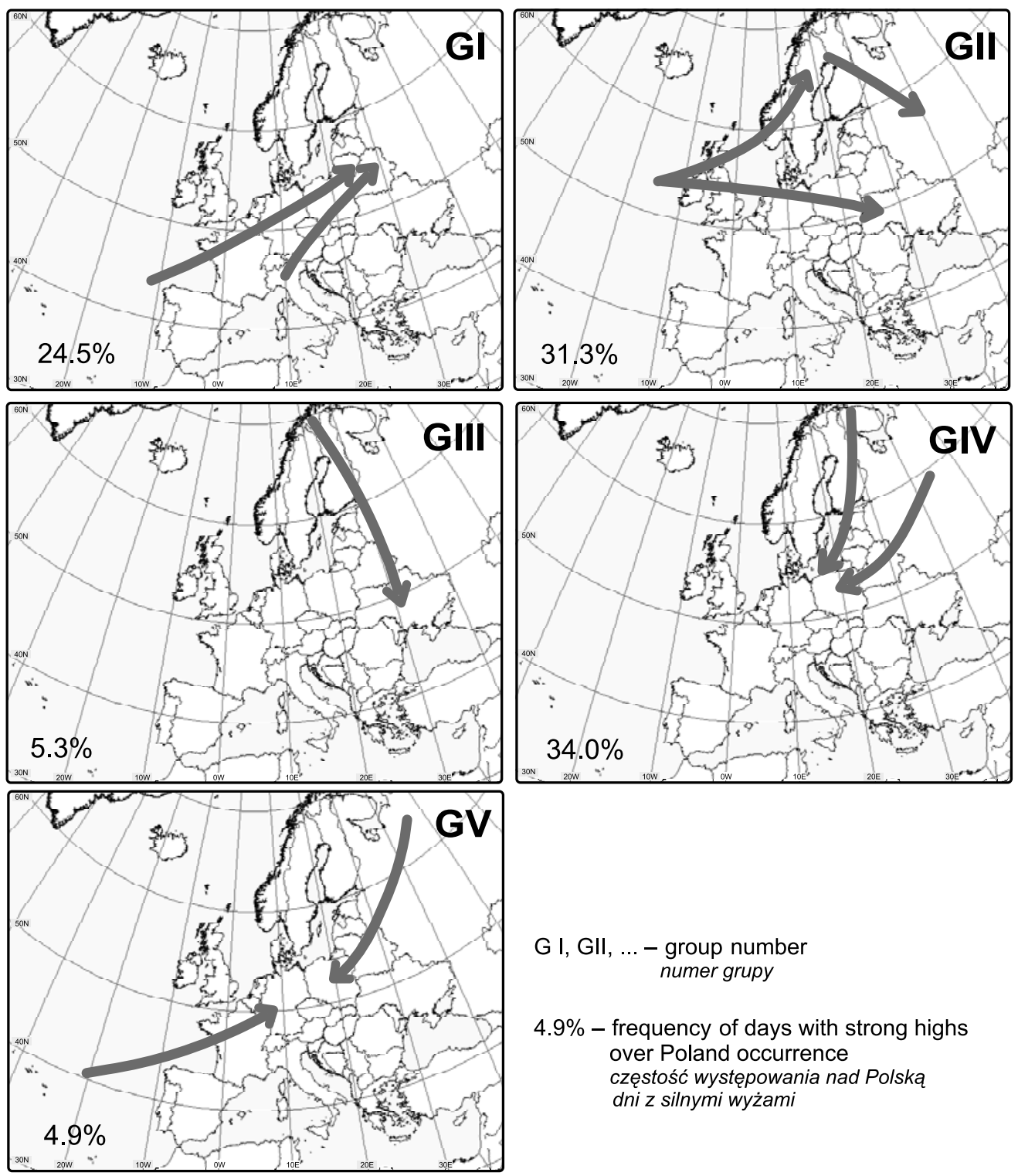

G I, GII, ... - group number numer grupy

\section{$4.9 \%$ - frequency of days with strong highs} over Poland occurrence częstość występowania nad Polską dni z silnymi wyżami

Fig. 2. The trajectories of strong highs influencing weather in Poland (1971-2000)

Ryc. 2. Szlaki silnych wyżów kształtujących pogodę w Polsce (1971-2000)

A budding high-pressure area would slowly move westwards and encompass much of Europe. In some cases it would stagnate around the source area without leaving the east of the continent. It would live for at least a dozen or so days and either decay or be pushed back eastwards by stronger centres in western Europe (Fig. 2). 
5) Group V (GV). A high-pressure zone would cover western and eastern Europe and would normally be divided by a low-pressure system or its trough. The low-pressure area would slowly disappear, allowing the two high-pressure areas to merge into an elongated high pressure ridge stretching from France across Poland to Russia; sometimes its axis would be shifted northwards, covering Scandinavia. In most cases the high over Russia would be stronger and lead to the formation of a strong Russian High (Fig. 2).

The research moved on to the stage of determining the duration of the influence exerted by the systems on the weather in Poland. The number of days with the identified systems ranged from 13 or 14 in Groups V and III respectively (4.9 and $5.3 \%$ of all events) to 90 days in Group IV (34\%) (Tab. 1). In most cases these were isolated days (41 cases), but also two-day sequences (29) and threeday sequences (20), while sequences lasting four days or longer ranged from two to 12 cases, depending on the group. Groups I, II and IV displayed similar trends, while in Groups III and V, with their low overall numbers of days, no single sequence exceeded four days and there were normally between one and four such ceases (Fig. 3). During the study period, the longest spell of a single high-pressure system was seven days, which was recorded on two occasions: in the first event a Group IV system spanned the end of 1972 and the beginning of 1973; in the second event (February 1993) a Group II strong high emerged to the west of British Isles and moved eastward.

Table 1. Number of days with strong high influencing weather in Poland classified into particular groups (1971-2000)

Tabela 1. Liczba dni z silnymi wyżami kształtującymi pogodę w Polsce w wydzielonych grupach (1971-2000)

\begin{tabular}{lcccccc}
\hline $\begin{array}{l}\text { Group number } \\
\text { Numer grupy }\end{array}$ & G I & G II & G III & G IV & G V & $\begin{array}{l}\text { Sum } \\
\text { Suma }\end{array}$ \\
\hline $\begin{array}{l}\text { Number of days } \\
\text { Liczba dni }\end{array}$ & 65 & 83 & 14 & 90 & 13 & 265 \\
$\begin{array}{l}\text { Frequency [\%] } \\
\text { Częstość [\%] }\end{array}$ & 24.5 & 31.3 & 5.3 & 34.0 & 4.9 & 100.0 \\
$\begin{array}{l}\text { Number of sequences } \\
\text { Liczba ciągów }\end{array}$ & 31 & 34 & 6 & 34 & 7 & 112 \\
\hline
\end{tabular}

Most of the identified systems that shaped the weather in Poland had their centres outside of the country's territory. Only on 76 (approx. 29\%) of the 265 days were the centres located over Poland. Most of these cases (43.4\%) were Group II systems originating over the northern Atlantic and building up eastwards. They were followed by (30-34\%) Group I systems emerged in south-western Europe 


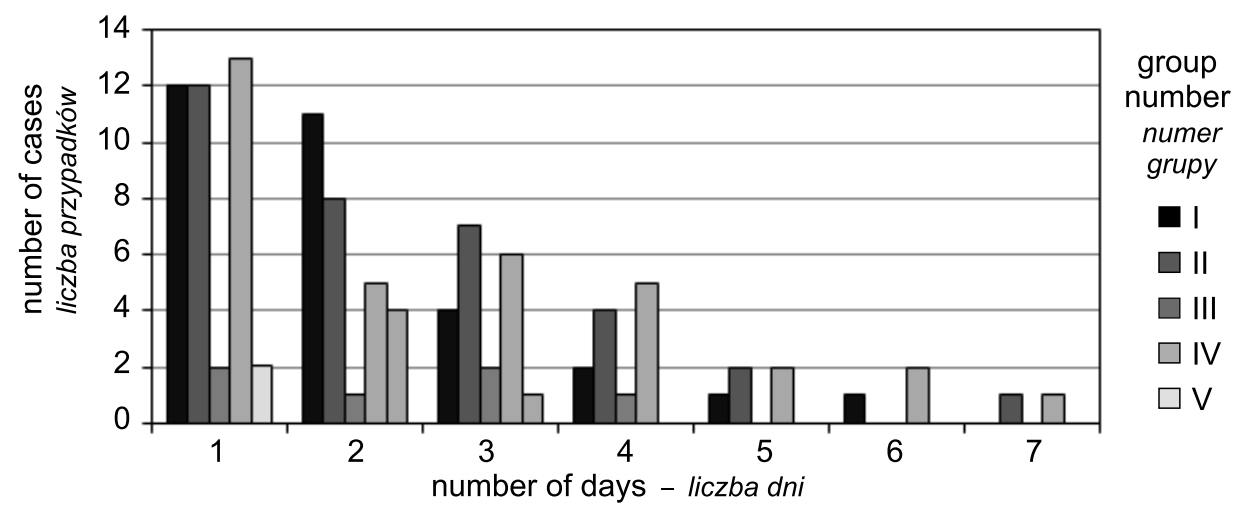

Fig. 3. Frequency [\%] of occurrence of sequences of strong highs influencing weather in Poland (1971-2000)

Ryc. 3. Częstość [\%] występowania ciągów dni z silnymi wyżami kształtującymi pogodę w Polsce (1971-2000)

and migrating eastwards and by the Group 5 high-pressure ridges crossing Europe. Only one in five (21.4\%) of Group III systems migrating from the north to the south of the continent had its centre over Poland. Finally, Group IV systems moving from the east and northeast contributed just $12.2 \%$ of all high-pressure centres over Polish territory.

A comparison of the centre pressure values revealed that the systems that emerged mainly in the Atlantic Ocean or in southern Europe (Groups I, II and V) featured mostly the pressure of $1040 \mathrm{hPa}(53.8-61.5 \%)$. Of the remaining centre pressures: Group I had mostly $1035 \mathrm{hPa}(33.8 \%)$, while Groups II and V had $1045 \mathrm{hPa}(21.7 \%$ and $23.1 \%$ respectively). Where the systems originated in the north or northeast of Europe (Groups III and IV) they normally displayed higher pressure values. Group III had the same figure of 35.7\% for both 1040 and $1045 \mathrm{hPa}$ central pressure values and $21.4 \%$ cases with $1050 \mathrm{hPa}$. Group IV had the highest centre pressures of all; it was dominated by $1045 \mathrm{hPa}(47.8 \%)$, had $12.2 \%$ of cases exceeding $1050 \mathrm{hPa}$, and two even higher cases with 1055 and $1060 \mathrm{hPa}$ (Tab. 2).

An analysis of relationship between the vertical extention and grouping of the high pressure systems revealed much weaker results than in other parameters. A clear majority of all systems were high (61.5-77.1\%). The highest proportion of medium-height systems were recorded in Groups V and III (30.8 and $28.6 \%$ respectively), while low-height systems ranged between 7.1 and $8.9 \%$ across all groups. 
Table 2. Centre pressure values of strong high influencing weather in Poland (1971-2000) Tabela 2. Ciśnienie w centrum silnych wyżów kształtujących pogodę w Polsce (1971-2000)

\begin{tabular}{|c|c|c|c|c|c|c|c|c|c|c|c|}
\hline \multirow{2}{*}{$\begin{array}{c}\text { Pressure } \\
\text { Ciśnienie } \\
\text { [hPa] }\end{array}$} & \multicolumn{6}{|c|}{ Number of days - Liczba dni } & \multicolumn{5}{|c|}{ Frequency [\%] - Częstość [\%] } \\
\hline & GI & GII & GIII & GIV & GV & $\begin{array}{l}\text { Sum } \\
\text { Suma }\end{array}$ & GI & GII & GIII & GIV & GV \\
\hline$(1035,1040)$ & 22 & 17 & 1 & 4 & 2 & 46 & 33.8 & 20.5 & 7.1 & 4.4 & 15.4 \\
\hline$(1040,1045)$ & 40 & 47 & 5 & 30 & 7 & 129 & 61.5 & 56.6 & 35.7 & 33.3 & 53.8 \\
\hline$(1045,1050)$ & 3 & 18 & 5 & 43 & 3 & 72 & 4.6 & 21.7 & 35.7 & 47.8 & 23.1 \\
\hline$(1050,1055)$ & 0 & 1 & 3 & 11 & 1 & 16 & 0.0 & 1.2 & 21.4 & 12.2 & 7.7 \\
\hline$(1055,1060)$ & 0 & 0 & 0 & 1 & 0 & 1 & 0.0 & 0.0 & 0.0 & 1.1 & 0.0 \\
\hline$\geq 1060$ & 0 & 0 & 0 & 1 & 0 & 1 & 0.0 & 0.0 & 0.0 & 1.1 & 0.0 \\
\hline Sum - Suma & 65 & 83 & 14 & 90 & 13 & 265 & 100.0 & 100.0 & 100.0 & 100.0 & 100.0 \\
\hline
\end{tabular}

\section{ANNUAL COURSE}

It also seemed interesting to ascertain any dependency between the annual course of high occurrence and the group of systems. High pressure systems developing in the western or southern section of the study area and moving eastwards (Groups I and II) and those moving westwards from the north or south of the continent (Group IV) were the most similar and occurred during all months of the cold half of the year (October to March). Group I systems occurred most frequently in January (33.8\% of all days) and stood out with a high October incidence (20.0\%). Group II recorded a stable rate of occurrence from December to February (20.5-24.1\%), but stood out with an appearance in May, while Group IV was distinguished by the highest frequency of occurrence in February $(30.0 \%)$. The other two groups clearly differed in their patterns. In Group III (migrating form north to south) all incidences were recorded during just three months: December (35.7\%), February (35.7\%) and March (28.6\%), with none in January. Group V (high pressure ridge) is distinct by its highest proportion of occurrence in February at $69.2 \%$ of all cases, as well as by a strong system in September (Fig. 4).

\section{LONG-TERM VARIABILITY}

A long-term analysis of the occurrence of strong high pressure systems spanning the study period yielded no statistically significant trends either in the whole sample or in any of the groups. On average there were approximately eight 

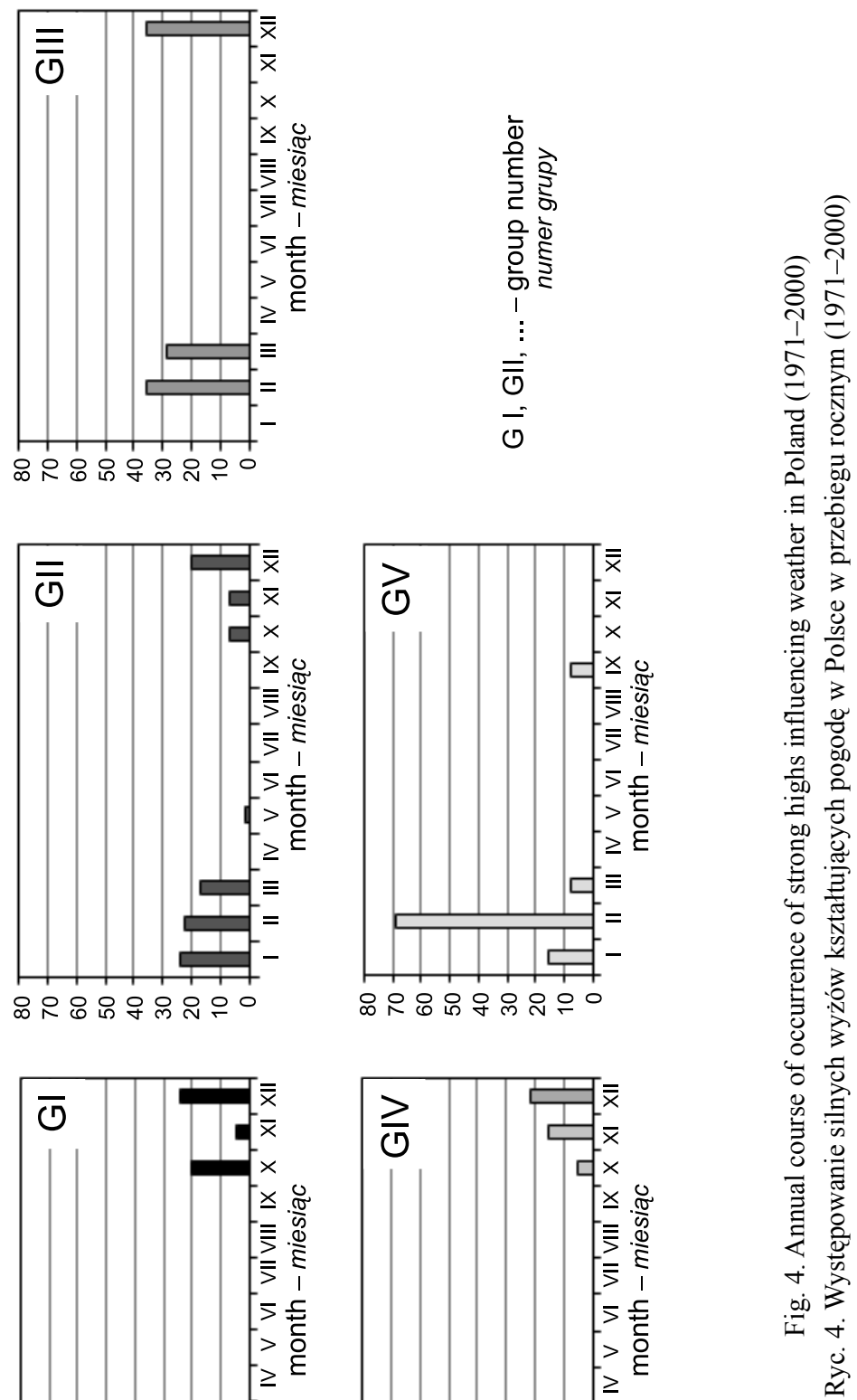

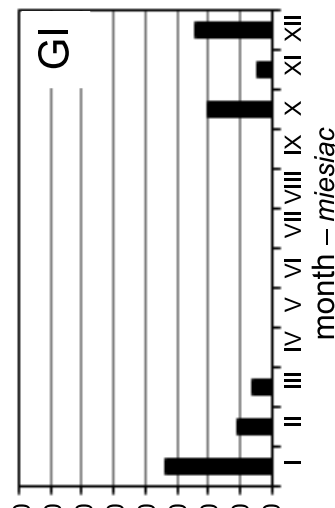

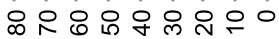

[\%] oșolsảzo

[\%] Kouənbərf

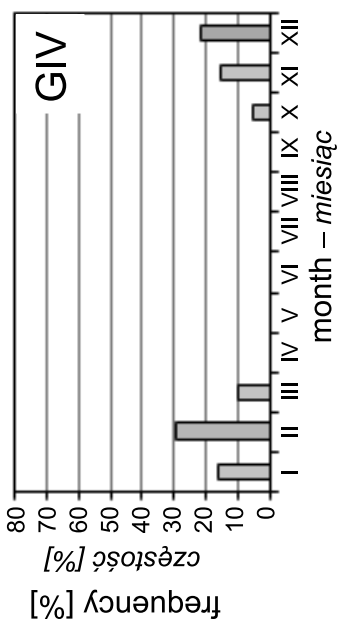

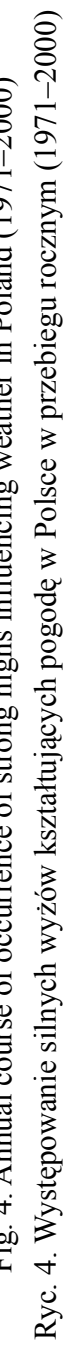


days in every year of the study period when Polish weather was shaped by extremely strong high pressure systems (Fig. 5). This number grew between 1970 and the early 1990s, after which it dived sharply until the end of the period. In 1978, there were no days with a strong high pressure system, and there was only one such day in 1999. The high-pressure systems were most frequent at the end of the 1980s and beginning of the 1990s and peaked in 1993 at 28 (January, February, October and November). During that year, almost all systems belonged to Groups I, II or IV (6, 7 and 13 days respectively), while the Group III systems migrating north to south were not represented at all. The increased overall rate of occurrence during the last two decades of the $20^{\text {th }} \mathrm{c}$. is likely to be linked to a growing frequency and persistence of wintertime high-pressure systems around the Mediterranean (Piervitali et al. 1997).

A long-term analysis of the occurrence of strong systems revealed similarities between the main three groups (I, II and IV). The greatest similarity was
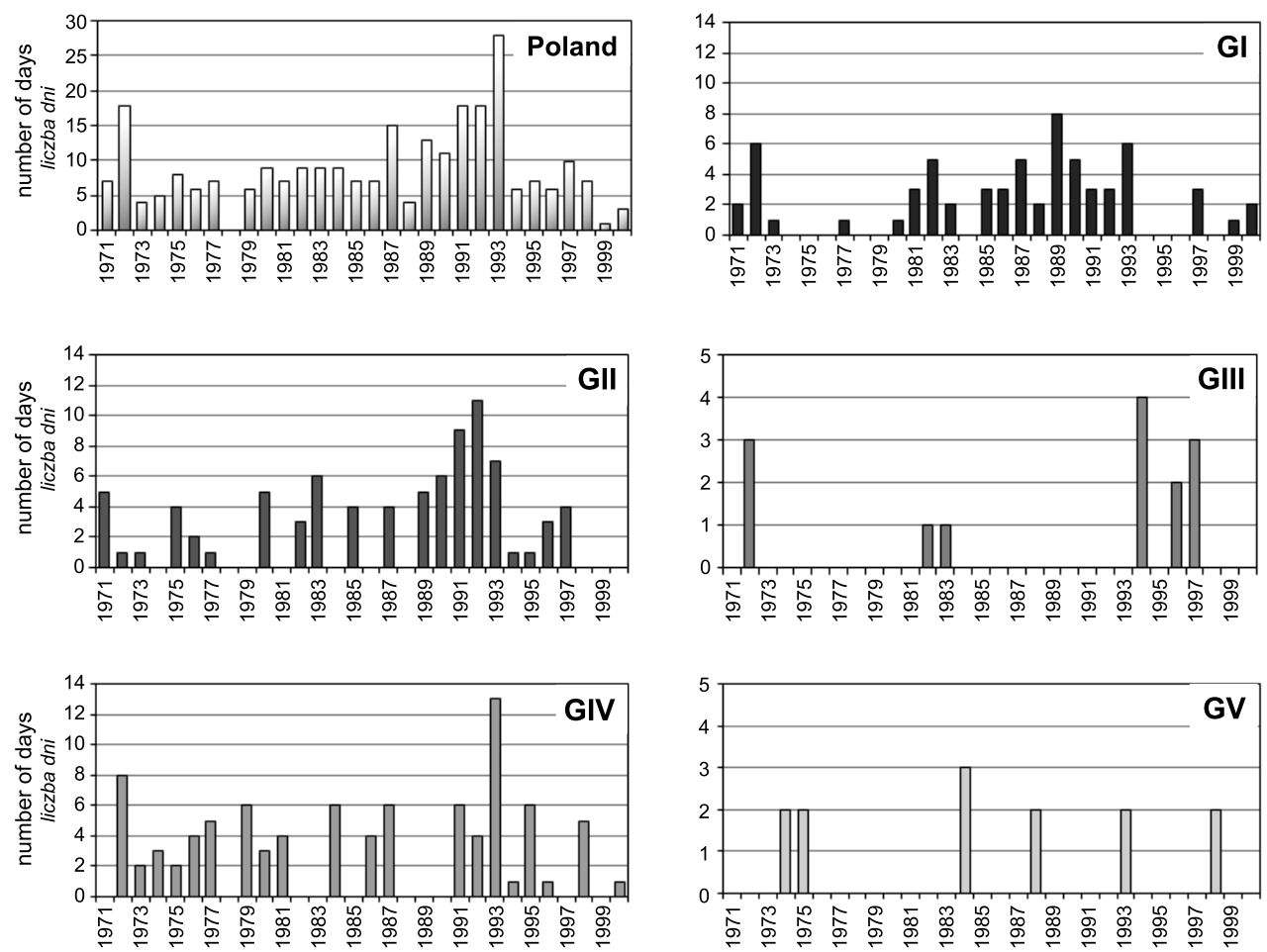

Fig. 5. Long-term variability of occurrence of strong highs influencing weather in Poland (1971-2000)

Ryc. 5. Wieloletnia zmienność występowania silnych wyżów kształtujących pogodę w Polsce (1971-2000) 
recorded between the high pressure systems of Groups I and II (correlation coefficient significant at 0.05 ). This is explained by their similar conditions of origin and subsequent development. All three groups contributed on average between two and three days each year of the study period. Group I systems were the least frequent during the first half and during the last seven years of the period (including 10 years when they did not occur at all); their largest numbers were recorded between 1981 and 1993, including eight days in 1989 (Fig. 5). The systems classified in Group II also occurred during 20 years. They peaked from 1989 to 1993 (11 days in 1992) and the only sustained spell without their incidence was during the last three years of the study period (Fig. 5). Group IV stands out by its higher occurrence rate during the first decade of the period and at the beginning of 1990 s, with 13 days in the peak year of 1993 . The systems were not recorded in 10 years, including the only longer empty spell of 1988-1990 (Fig. 5). The numbers in Groups III and V were not large enough to speak of any long-term variability, and their the largest number of days during the year never exceeded four (Fig. 5).

\section{CONCLUSION}

The results obtained in the study reveal that very strong high-pressure systems influence Polish weather quite infrequently. During the study period this happened on average on eight days in a year, although there were 28 such days during the peak year of 1993. In most cases the high pressure situations lasted between one and three days (ca. $80 \%$ of all cases) and there were only 22 events when they exceeded that number.

The entire sample of strong high pressure systems was broken down into five groups according to their source area and subsequent development patterns. The greatest differences were identified when analysing their annual and long-term occurrence patterns, followed by a comparison of their centre pressure values and the location of their centre with relation to Polish territory. In most cases Poland was under the influence of systems whose centres were located outside the country's borders. Only approximately $30 \%$ of days with a strong high pressure influence involved a system centred over Poland; these were mostly systems moving from west to east (Group V) or, least frequently, those moving from their source areas located to the east or northeast of Poland (Group IV). The latter group, however, featured the highest air pressures, including more than $60 \%$ of cases above $1045 \mathrm{hPa}$. Other groups normally featured between 1040 and 1045 $\mathrm{hPa}$ at the centre.

All of the identified systems, except for two cases, occurred during the cold half of the year, although the differences between individual groups were quite substantial. Groups III and V were the most distinctive and contributed the 
lowest number of days overall. Group III systems occurred only in December, February and March and 69\% of days with the Group V system concentrated in February.

The study identified no statistically significant trend of change in the number of days when Poland was under an influence of a strong high pressure system. What is distinguishable, however, is a rather sharp increase in the number of days in the late 1980s and early 1990s, which coincides with an increased number of strong high pressure systems around the Mediterranean reported in the subject literature.

\section{REFERENCES}

Baldi M., Pasqui M., Cesarone F., de Chaira G., 2006: Heat waves in the Mediterranean region: Analysis and model results. Int. J. Climatol., 26, 1477-1487.

Barnett T.P., 1988: Variation in near-global sea level pressure: Another view. J. Climatol., 1, 225-230.

Bengtsson L., Hodges I.K., 2006: Storm tracks and climate change. J. Climatol., 19, 3518-3543.

Bielec-Bakowska Z., 2007: Występowanie głębokich niżów i silnych wyżów nad Polska (19712000). [In:] K. Piotrowicz, R. Twardosz (eds), Wahania klimatu w różnych skalach przestrzennych $i$ czasowych. IGiGP UJ, Kraków, 65-74.

Brunetti M., Maugeri M., Nanni T., 2002: Atmospheric circulation and precipitation in Italy for the last 50 years. Int. J. Climatol., 22, 1455-1471.

Brunetti M., Maugeri M., Nanni T., Navarra A., 2001: Droughts and extreme events in regional daily Italian precipitation series. Int. J. Climatol., 2, 543-558.

Cornford S.G., 2002: Hunan and economic impacts of weather events in 2001. Bulletin of the WMO, 51, 257-277.

Degirmendžić J., 1998: Wpływ Wyżu Azjatyckiego na temperature powietrza na powierzchni izobarycznej 850 hPa nad Europa. Disertation, Uniw. Łódzki, Łódź.

Degirmendžić J., Kożuchowski K., Żmudzka E., 2004: Changes o fair temperature and precipitation in Poland in the period 1951-2000 and their relationship to atmospheric circulation. Int. J. Climatol., 24, 291-310.

Hafez Y.Y., 2007: The connection between the 500 hPa geopotentiol hight anomalies over Europe and the abnormal weather in Eastern Mediterranean during winter 2006. Int. J. Meteorol., 32, 335-348.

Hoskins B.J., 2002: New perspective on the Northern Hemisphere winter storm tracks. J. Atmos. Sci., 59, 1041-1061.

Hurrel J.W., Loon van H., 1997: Decadal variations in climate associated with the North Atlantic Oscillation. Clim. Change, 36, 301-306.

Kalnay E., Kanamitsu M., Kistler R., Collins W., Deaven D., Gandin L., Iredell M., Saha S., White G., Woollen J., Zhu Y., Chelliah M., Ebisuzaki W., Higgins W., Janowiak J., Mo K.C., Ropelewski C., Wang J., Leetmaa A., Reynolds R., Jenne R., Joseph D., 1996: The NCEP/NCAR 40-Year Reanalysis Project. Bull. Am. Met. Soc., 77, 437-471.

Kłysik K., 1995: Rola silnych wyżów i glębokich niżów w ksztaltowaniu warunków termicznych okresu zimowego w Europie Środkowej. [In:] B. Krawczyk, K. Błażejczyk (eds), Współczesne badania klimatologiczne. Conf. Papers, 23 IGiPZ PAN, Warszawa, 19-27.

Knippertz P., Ulbrich U., Speth P., 2000: Changing cyclones and surface wind speeds over the North Atlantic and Europe In a transient GHG experiment. Clim. Res., 15, 109-122. 
Kożuchowski K., 1993: Makrotypy ogólnej cyrkulacji atmosfery a główne typy cyrkulacji nad Polska. Przegl. Geofiz., 38(3-4), 241-247.

Kożuchowski K., 1995: Gtębokie cyklony i antycyklony i cyrkulacja strefowa nad Europa (19001990). Przegl. Geofiz., 40(3), 231-246.

Leckebusch G.C., Ulbrich U., 2004: On the relationship between cyclones and extreme windstorm events over Europe under climate change. Global Planet Change, 44(1-4), 181-193.

Luterbacher J., Xoplaki E., Dietrich D., Rickli R., Jacobeit J., Beck C., Gyalistras D., Schmutz C., Wanner H., 2002: Reconstruction of sea level pressure fields over the eastern North Atlantic and Europe back to 1500. Clim. Dyn., 18, 545-561.

Marsz A., Żmudzka E., 1999: Oscylacja Pótnocnego Atlantyku a dtugość okresu wegetacyjnego $w$ Polsce. Przegl. Geofiz., 44(4), 199-210.

Michaels P.J., Knappenberger P.C., Balling Jr R.C., Davis R.E., 2000: Observed warming in cold anticyclones. Clim. Res., 14, 1-6.

Niedźwiedź T., 1996: Long-term variability of the zonal circulation index above the Central Europe. Zesz. Nauk. UJ, Pr. Geogr., 102, 213-219.

Piervitali E., Colacino M., Conte M., 1997: Signals of climatic change in the central-western Mediterranean basin. Theor. Appl. Climatol., 58, 211-219.

Romem M., Ziv B., Saaroni H., 2007: Scenarios in the development of Mediterranean cyclones. Adv. Geosci., 12, 59-65.

Sinclair M.R., 1997: Objective identification of cyclones and their circulation intensity, and climatology. Wea. Forecasting, 12, 595-612.

Trenberth K.E., Paolino D.A., 1980: The Northern Hemisphere sea-level pressure data set: Trends, errors and discontinuities. Mon. Wea. Rev., 108, 855-872.

Trenberth K.E., Paolino D.A., 1981: Characteristic patterns of variability of sea level pressure in the Northern Hemisphere. Mon. Wea. Rev., 109, 1169-1189.

Trepińska J., Piotrowicz K., Bąkowski R., Bolechała F., 2006: Pogoda a samobójstwa. Balneologia Polska, 48(1), 51-55.

Ulbricht U., Fink A.H., Klawa M., Pinto J.G., 2001: Three extreme storms over Europe in December 1999. Weather, 56, 70-80.

Ustrnul Z., 1997: Zmienność cyrkulacji atmosfery na pótkuli pótnocnej w XX wieku. Mat. Badawcze IMGW, Ser. Meteorologia, 27, Warszawa.

Wibig J., 1999a: Cyrkulacja atmosferyczna nad Europq na powierzchni izobarycznej 500 hPa. Część I: Zima. Przegl. Geofiz., 44(1-2), 15-24.

Wibig J., 1999b: Cyrkulacja atmosferyczna nad Europq na powierzchni izobarycznej 500 hPa. Część II: Wiosna, lato, jesień. Przegl. Geofiz., 44(1-2), 25-38.

Wibig J., 1999c: Precipitation in Europe in relation to circulation patterns at the $500 \mathrm{hPa}$ level. Int. J. Climatol., 19, 253-269. 